\title{
Images to raise our gaze: Fragments from a conversation with Luis Ospina and Camilo Restrepo
}

In this conversation, Luis Ospina and Camilo Restrepo, two filmmakers who personify two periods in Colombian cinema and history, reflect on the presence of dead bodies in cinema and, particularly, of corpses as a filmic matter in their respective works and poetics. On the basis of a similar questionnaire carried out simultaneously with each filmmaker, the text brings together common and dissonant motifs to outline a possible generational arc of Colombian cinema in which the cinematographic representation of the corpse is presented as a historiographical and political motif in order to carry out an interpretation of cinema and history.

Keywords

CORPSE

HISTORY

MEMORY

COLOMBIAN CINEMA

VIOLENCE

BIPARTISAN VIOLENCE

FALSE POSITIVES

COLOMBIAN ARMED CONFLICT

\section{Date of reception: 15/10/2018}

Date of acceptance: 06/05/2019

Luis Ospina (Cali, Colombia, 1949 - Bogotá, Colombia, 2019) Filmmaker. Co-founder, along with Andrés Caicedo, Carlos Mayolo, and Ramiro Arbeláez, of the journal Ojo al Cine (1974-77). He directed over 40 films, including feature films, documentaries and video-art pieces, was scriptwriter and director of the film Pure Blood (Pura sangre, 1982), and co-director, along with Carlos Mayolo, of The Vampires of Poverty (Agarrando pueblo, 1977). Editor of the feature films Bloody Flesh (Carne de tu carne, 1983) and The Manor of Araucaima (La mansión de Araucaima, 1986) by Carlos Mayolo, among others. He was the Creative Director of the Cali International Film Festival since 2009 until his death.

Camilo Restrepo (Medellín, Colombia, 1975) He has lived and worked in Paris since 1999. He is a member of L'Abominable, an independent laboratory of filmmakers working in celluloid. His filmography includes four short films, notably Impressions of a War (La impresión de una guerra, 2015) and Cilaos (2016), both of them winners of the Pardino d'Argento at the Locarno Film Festival. Impressions of a War has also won seven other awards in festivals.

Carolina Sourdis Doctor of Cinema Studies from Universitat Pompeu Fabra, where she is an Adjunct Lecturer. Her visual pieces have been screened at festivals in Spain, Colombia and Iran. She has contributed to the book Archivo, memoria y presente en el cine latinoamericano and has published articles in several journals, including Cuadernos del Cine Colombiano, Cinema Comparat/ive Cinema and New Cinemas: Journal of Contemporary Film. 
No. We did not come to this world to stay. We came to pass through it like the wind and then die. Sometimes the passing of that wind creates havoc, and has a name: its name is Pablo Escobar, Miguel Rodríguez Orejuela, Carlos Castaño, Tirofijo, Gaviria, Samper, Pastrana. Learn as you give proper names to infamy.

A los muchachos de Colombia

("To the kids of Colombia"), Fernando Vallejo

In this conversation, Luis Ospina and Camilo Restrepo, two filmmakers who personify two periods in Colombian cinema and history, reflect on the presence of dead bodies in cinema and, particularly, on corpses as a filmic matter in their respective works and poetics. Based on a similar questionnaire carried out simultaneously ${ }^{1}$ and by arranging these interview fragments, we have attempted to bring together common and dissonant motifs to outline a possible generational arc of Colombian cinema. In this outline, the cinematographic representation of the corpse allows us to emphasize and tear apart the layers of a reality (one that is mercenary, violent and atrocious; cynically cyclical in that it is simultaneously history and the present) which exceeds all the edges of the imaginable.

Therefore, this conversation is not really a conversation as such: the notes and questions formulated as the driving force for each motif throughout the text emerge later on, when they are linked to the thoughts of Ospina (LO) and Restrepo (CR) after their answers to a classic questionnaire have been broken down and edited. In fact, it's more like a virtual contact between the filmmakers and their ideas (as well as between the text's questions and answers) for the purpose of establishing possible links between death and the body, memory and history, based on images of corpses in cinema.

\footnotetext{
* The conversation with Luis Ospina took place in his apartment in Bogotá in Summer 2018. During the interview, he gave us a gift that he had kept from the 1980s: a copy of Crónica Roja, the newspaper made for the promotion of his film Pure Blood. He also gave us a lot of his time, with his usual, deep generosity, his everlasting humility and his wise black humour. Luis got to read this conversation in the format of its publication and sent us the images of his "own collection of dead", which in his view fitted it better. He died shortly before the publishing of this volume, the 27th of September 2019.
} 

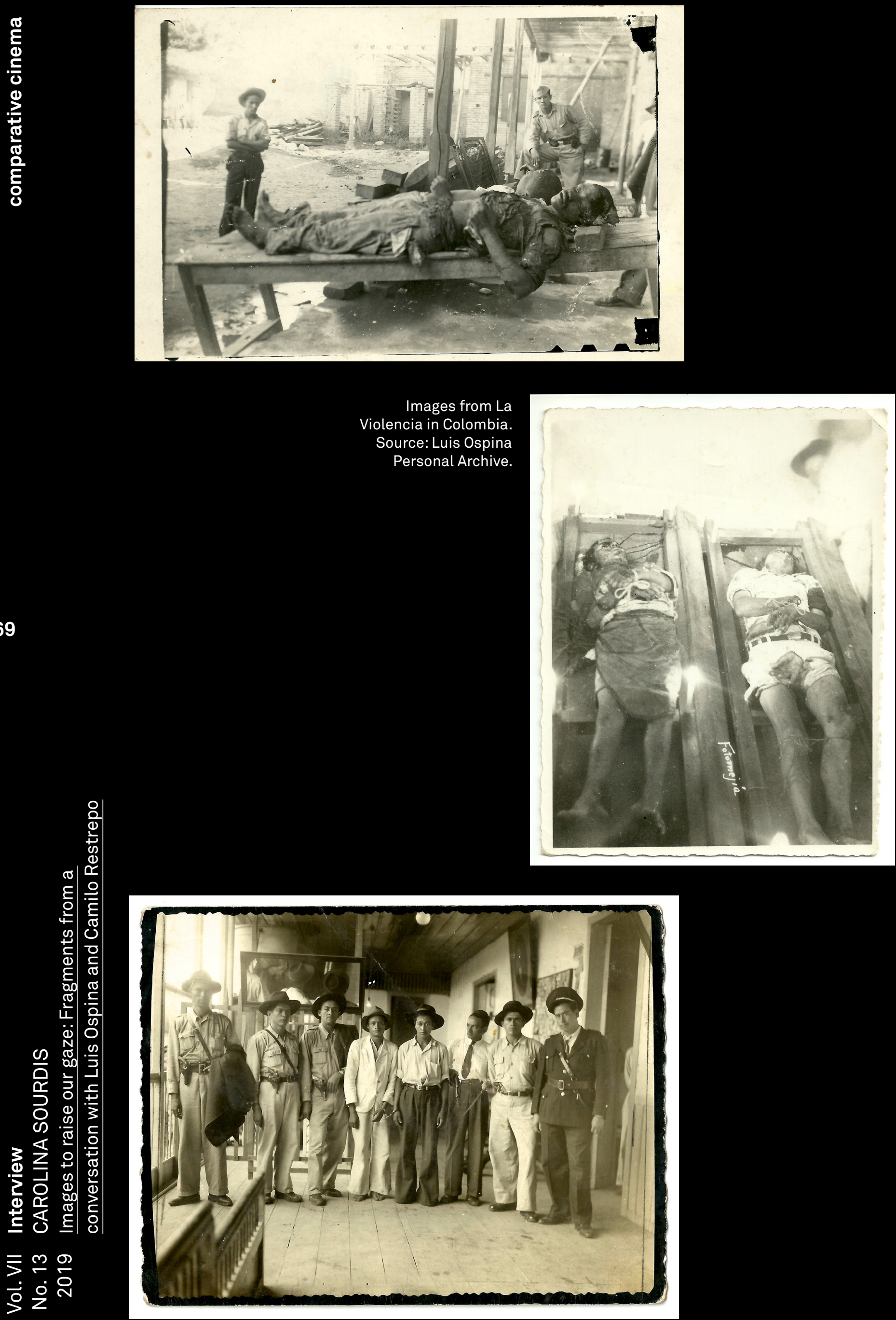


\section{Cycles of violence in Colombia}

Throughout its history, Colombian cinema has emphatically addressed the portrayal of the so-called period of La Violencia ("The Violence") ${ }^{2}$, as well as other types of violence related to the armed conflict and the social and political consequences of war: The River of the Graves (El río de las tumbas, Julio Luzardo, 1964), A Man of Principle (Cóndores no entierran todos los días, Francisco Norden, 1984) and Confessing to Laura (Confesión a Laura, Jaime Osorio, 1990), to name just a few. Could images of the dead body represent at the same time a visual, political and historiographical motif throughout that history?

L 0

When they screened that great season of Colombian cinema at the recently-inaugurated Cinemateca Distrital in Bogotá (a season which was, for me, the first big one in Colombian cinema), I saw what may have been the first fiction film to address the topic of La Violencia - a short film called Esta fue mi vereda ("That Was My Path", Gonzalo Canal Ramírez, 1959). Among all these films there were others like Aquileo venganza (“Achilleion Vengeance", Ciro Durán, 1968), a kind of Colombian western, and the political films of that period, which always deal with themes of violence, like Camilo Torres by Diego León Giraldo (1966), which was made almost immediately after the death of Camilo Torres, a highly urgent film. In fact, one of the corpse images that I remember most is precisely that one: Camilo's corpse; I use it in my film A Paper Tiger (Un tigre de papel, 2007). But there are so many deaths in Colombia... For me, the most shocking images of corpses are the ones resulting from the bipartisan violence - seeing the degree of sophistication it reached, how they killed people. There is a theory that claims that, in the times of La Violencia, these people killed so much and in such a way that they began stylizing the mechanisms of death so that people would recall, in their next life, how much they suffered before dying. They even wanted to punish them in their next life! They did such dreadful things. This is similar to the paramilitaries, many years later, with some horrible situations: when they played soccer with people's heads, or the "False positives" scandal. l've never addressed the subject of the paramilitaries, though, because l've focused on other historical periods. I've got up to the last century.

\section{R} In the context of Colombia you don't need to look far to find the imaginary that could be represented by the excessive images 


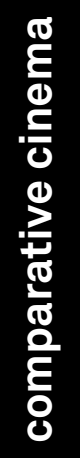

Back view of corpses:

Pure Blood (Luis

Ospina, 1982) and

Impression of a War

(Camilo Restrepo,

2015).
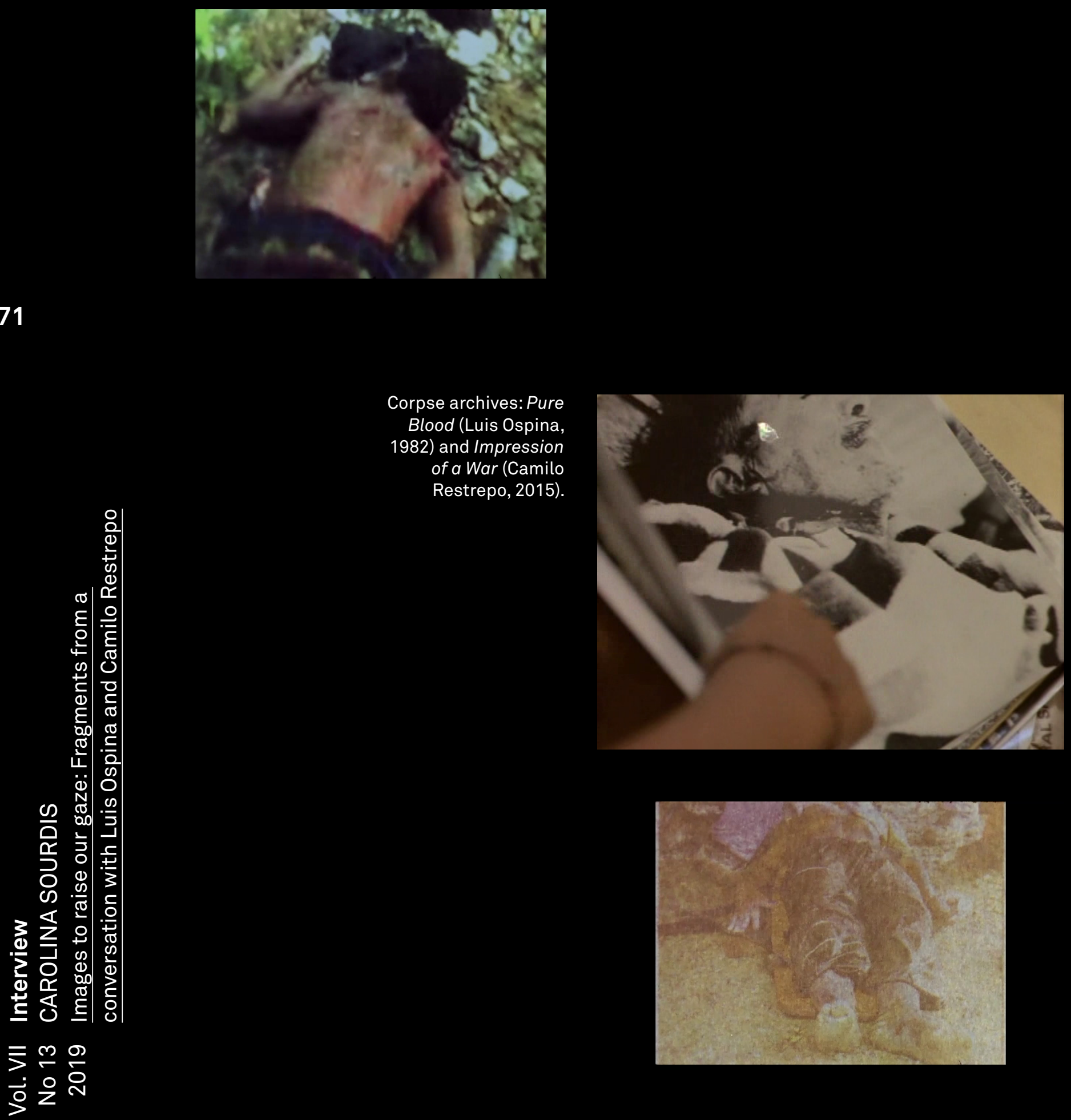

Corpse archives: Pure

Blood (Luis Ospina

1982) and Impression

of a War (Camilo

Restrepo, 2015).

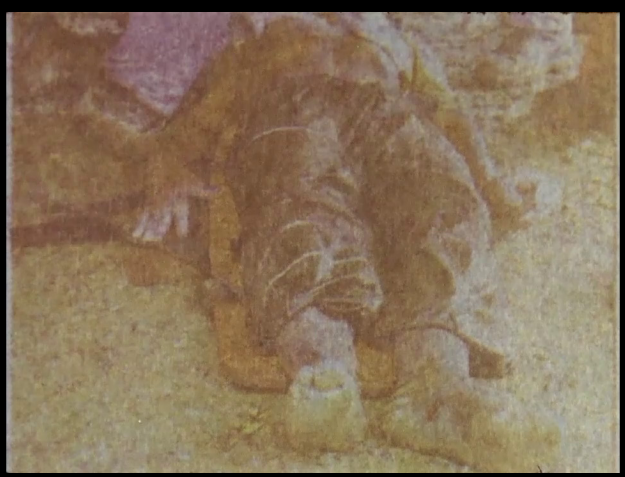


of corpses: the constant threat of living in a society ruled by the law of "might equals right", immersed in total chaos and a trivialized injustice. The Colombian Mad Max, to put it simply. An imaginary that is no more than a projection (aggravated, or perhaps not...) of the day-to-day life of many Colombians. The poet Gonzalo Arango envisaged the resurrection of the great bandits of that time known as La Violencia using terms like the "living dead". His poem Elegía a Desquite ("Elegy to Desquite") ends like this: "Is there no way that Colombia, instead of killing its children, can make them worthy of life? If Colombia cannot answer this question, then I foresee a tragedy: Desquite will return from the dead, and the earth will be soaked in blood, pain, and tears".

As a matter of fact, Desquite ("Revenge") is a character who will be appearing in my next film. Born into a rural family in 1936, he took up arms at the age of 14 after suffering several injustices. He made an unsuccessful attempt to join the Army and then tried life as a civilian, but it seems that his destiny was to be a bandit. He embodied the figure of the good bandit, a kind of Robin Hood, half-robber, half-guerrilla. But in fact he wasn't always good; he could be ruthless and cruel, just like the government was at that time. When the Army finally killed him in 1964, his corpse was displayed in the main square of several towns so the people would realize that "the bandit empire was collapsing". But as Gonzalo Arango said, Desquite will return for revenge once again, because the bandit empire has not collapsed yet, because the bandit governments are not finished yet.

\section{From documentary evidence to the figuration of the corpse}

The documentary collection of images showing attacks, massacres and murders committed in the country, either by insurgency, paramilitaries or drug trafficking-related groups, defies all possible imaginary of evil: the reality exceeds any notion of brutality. Meanwhile, the images are displayed, broadcasted by the media and consumed by viewers; they are well-known images for the public, who have in some way come to accept them. Is it possible to transform the documentary evidence of disaster into an image that succeeds in challenging an anesthetized gaze? How to convert a testimonial image into the seed of filmic matter? How have images of horror determined the imaginaries for representing the body in Colombian cinema? 
The first image of a corpse that I saw was in my father's collection of Life magazines. He had bound all the Life magazines from the late 1930s, the entire period of war until that moment, which was the early 1960s. I remember seeing corpses from World War II; they made a big impression on me, especially the photos of the corpses in the Normandy landings. I think the first images of Colombian corpses I saw were the ones that appeared in the Cali newspapers at that time, El Relator and El País. You could often see in the newspapers those images of corpses piled up, people whose throats had been slit using those extremely sophisticated methods adopted by the bandits of the time, with their ties cut, their vests cut, beheadings... In short, all of us who grew up during that period saw those horrendous images. Later on, when the book La violencia en Colombia ("Violence in Colombia"), by Monsignor Guzmán Campos, Orlando Fals Borda and Eduardo Umaña Luna, came out, almost every home in Colombia had it. It was certainly a book about violence with a capital $V$, about the bipartisan struggle between liberals and conservatives. The book had photos, and they made a big impact on me. I know this was also the case with Carlos Mayolo, because we grew up more or less in the same context and time.

Other images that had a great impact on me were the ones of the mutilated, destroyed corpses from the August 7th 1956 explosion in Cali, when I was seven. It was a famous explosion, and the casualty figures have never been verified. The highest figures suggest three thousand dead, with other estimates lower. The explosion happened because the Rojas Pinilla government was transporting a load of dynamite from Buenaventura to Cali and they parked a dozen loaded trucks in what was called the red zone, the tolerance zone. No one ever knew why it blew up, but at around one in the morning the truck created a huge blast wave that destroyed part of my house. That's why we had to move to my grandma's place, in front of where Mayolo lived.

My mom worked as a volunteer at the site of the tragedy, and she told us lurid tales of how people began mutilating corpses to steal rings, looting, it was awful. And another awful thing was that, because the explosion happened near the main graveyard, the blast wave propelled the dead from their graves. I found a newsreel in the Patrimonio Fílmico archive that was called Tragedia in Cali ("Tragedy in Cali"), it's featured in two of my films: in It All Started At the End (Todo comenzó por el fin, 2015) and in the series Cali: Yesterday, Today and Tomorrow (Cali, ayer hoy y mañana, 1995). It is a very well-shot piece of footage by 


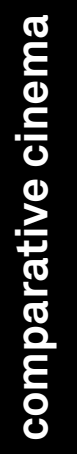

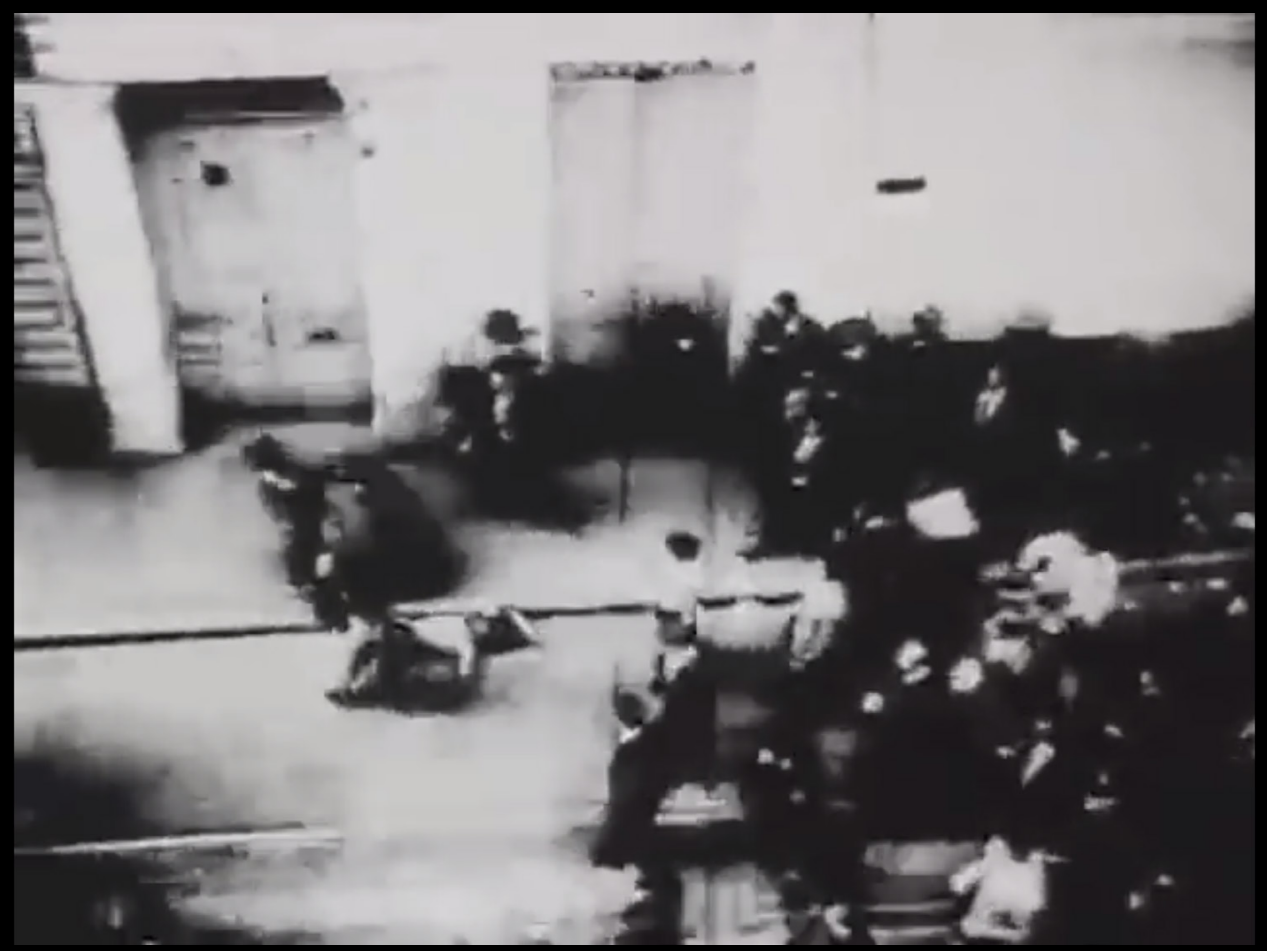

Roa Sierra is dragged naked along the Carrera Séptima. 
a man called Ramón Carthy, Venezuelan, and it's like a short documentary of what happened on August 7 1956. Mayolo created Bloody Flesh (Carne de tu carne, 1983) based on this event, he used this precise historical moment to establish the incest story.

Meanwhile, I also experienced the Vietnam War at close hand, in a way. I was studying in the United States at the time. There are two images of death being filmed that you can't forget: one is the image of a Vietnamese officer killing a Viet Cong, he shoots him, and it's filmed; and then the image of a naked girl burnt by napalm. From the Spanish Civil War, there's the emblematic shot by Robert Capa which shows a man who's been shot in the head. By the way, there's a whole school of thought that claims the photo is fake, and that it wasn't taken there, and it's disappointing to think that what is possibly the most iconic image of the Spanish Civil War might have been staged. But that is where we come to the question of how to stage a death, or how it can be faked. That might also take us back to the early years of Colombian cinema, to that now-disappeared film El drama del 15 de Octubre ("The October 15 Drama", Francesco Di Domenico, 1915), in which there is a real murder, that of Rafael Uribe Uribe, and the murderers play a role in the film; it's staged and the reality is falsified by adding scenes from other burials. One of the most shocking moving images is the scene in which Roa Sierra, killer of Jorge Eliecer Gaitán, is dragged naked along the Carrera Séptima ("Seventh Street"). I use these images in A Paper Tiger; and they're also in the film Confessing to Laura by Jaime Osorio and in many Colombian and foreign films. It's very similar to the images of the corpses of Mussolini and Clara Petacci, when they were killed and stripped.

\section{R}

I think that from one work to another, I have stopped using corpses in my films in order to focus more on death. In other words, relinquishing the specific event in order to lose myself in the abstraction of the idea. I'll try to summarize this journey in a few words.

In my first short films, I asked myself the following question: can the examination of a particular death shed some light to help us to understand all those millions of dead in a war? This question was aimed at the subject of the Colombian armed conflict and the various types of civilian and political violence that have taken place in this conflict. Obviously, this question is not valid without its corollary: can the way people die in a society shine a light on the way people live in that society? Because in the end, 
thinking about death only makes sense if you're thinking about living.

Within these two questions I addressed (among other events) the massacre known as the "False positives". People murdered by the Colombian army in a staged setting in which soldiers dressed up civilians as guerrillas (before or after killing them) with the aim of boosting the figures of people "killed in action", and which would legitimize the government's task of fighting the guerrillas. The manipulation of information (propaganda about the alleged success of the anti-guerrilla struggle) began with the physical manipulation of the corpses, dressing them up as guerrillas where the massacre took place. The staging and the truth of the events came to light because the manipulation wasn't exact and hadn't been done very well (boots put on backwards, to give just one example). During these events, the soldiers filmed the corpses with their mobile phones so the images would serve as proof of their work's success. However, those same soldiers, filmed their own rest and relaxation activities with those same phones, thereby creating a contrast between their happy leisure hours and their work as murderers. The image of a euphoric soldier enabled viewers to realize the distance that separated him from the corpse he'd left behind. In my film Impression of a War (La impresión de una guerra, 2015) I compared the corpses of dead civilians to another kind of "still lives", speaking in terms of representation. I then considered the corpse as an object amongst other objects. As an object, the corpse is open to manipulation in the broadest sense of the word. The manipulation of this object/corpse was precisely one of the starting points for my empirical analysis of the Colombian armed conflict and its various types of civilian and political violence.

By the time I was making my last short films, I stopped considering the image of the corpse, instead moving on to film characters who were alive, who walked through death, and who talked to and sang to the dead. One possible reason for this change was this: when we are faced with a corpse we have to speak for it ourselves, and I - for a long time ago now wanted the dead to speak their own message, for themselves, with their own words and mouths. That was how I decided to approach fiction: by facing the immensity of death as a space of imagination, and no longer by simply showing the detail of the corpse as documental evidence. 
The first physical corpse that I saw was a block and a half away from my place, when I was about 13 or 14 years old. I saw a crowd on a piece of waste ground that we call mangones ("pastures") in Cali, and I had a peek to see what was happening. There was the swollen, naked corpse of a boy. That was during the time of the famous serial killer called the "Monster of the Mangones", who killed around 13 children; he raped them, sometimes they were found with a hole in their hearts. The people's imagination began to create an urban legend about who that monster might be, and they said that the child victims had been drained of their blood, because there was a very rich man in Cali who had a strange disease for which he needed children's blood. It was a time of terror, and they told us "Don't go out into the street, not this late!", because you might end up in the hands of that monster. That was the first corpse I ever saw; it was also shocking because it was a boy, maybe younger than me. It had such an impact. This urban legend is what I later used to make the film Pure Blood (Pura sangre, 1982).

In this film I recreate the scene in which I saw that first corpse. In fact, that recreation appears in one of the newspapers we created to promote the film - Crónica Roja ("Crime Report"). We distributed the newspaper ourselves on the streets when the movie came out, and we also added the story of the monster, how it was linked to Dracula. Babalú also appears - that black, insane character whose eyes are always out of proportion, and who takes the credit for killing the victims of the "Monster of the Mangones" at the end of the film. He was actually a stagehand, not an actor, and the speech he gives was taken from a feature I saw about the Monster of the Andes, while another part was taken from a famous crazy man in Cali, a stoner, a friend of mine who suffered from Tourette's syndrome and who used to talk all kinds of nonsense. They called him "el loco Guerra" ("Crazy Guerra"), I even have a small ceramic statue of him, he was a typical character, a typical madman from Cali. He had some powerful rage attacks and he had a very aggressive way of speaking, so I took those two texts and combined them. I rehearsed with this guy for almost three months until I got what I wanted. In actual facts, they never caught the murderer, and the crimes of the "Monster of the Mangones" went unpunished. I think l've been obsessed with death since I was a child, perhaps precisely because I grew up in that period of the 1950s, when death was always on the front pages. I have my collection of dead people, it includes a small collection of photos of La Violencia in Colombia, from the 1950s, among other things. I photographed the first image in this collection in Bogotá, when 


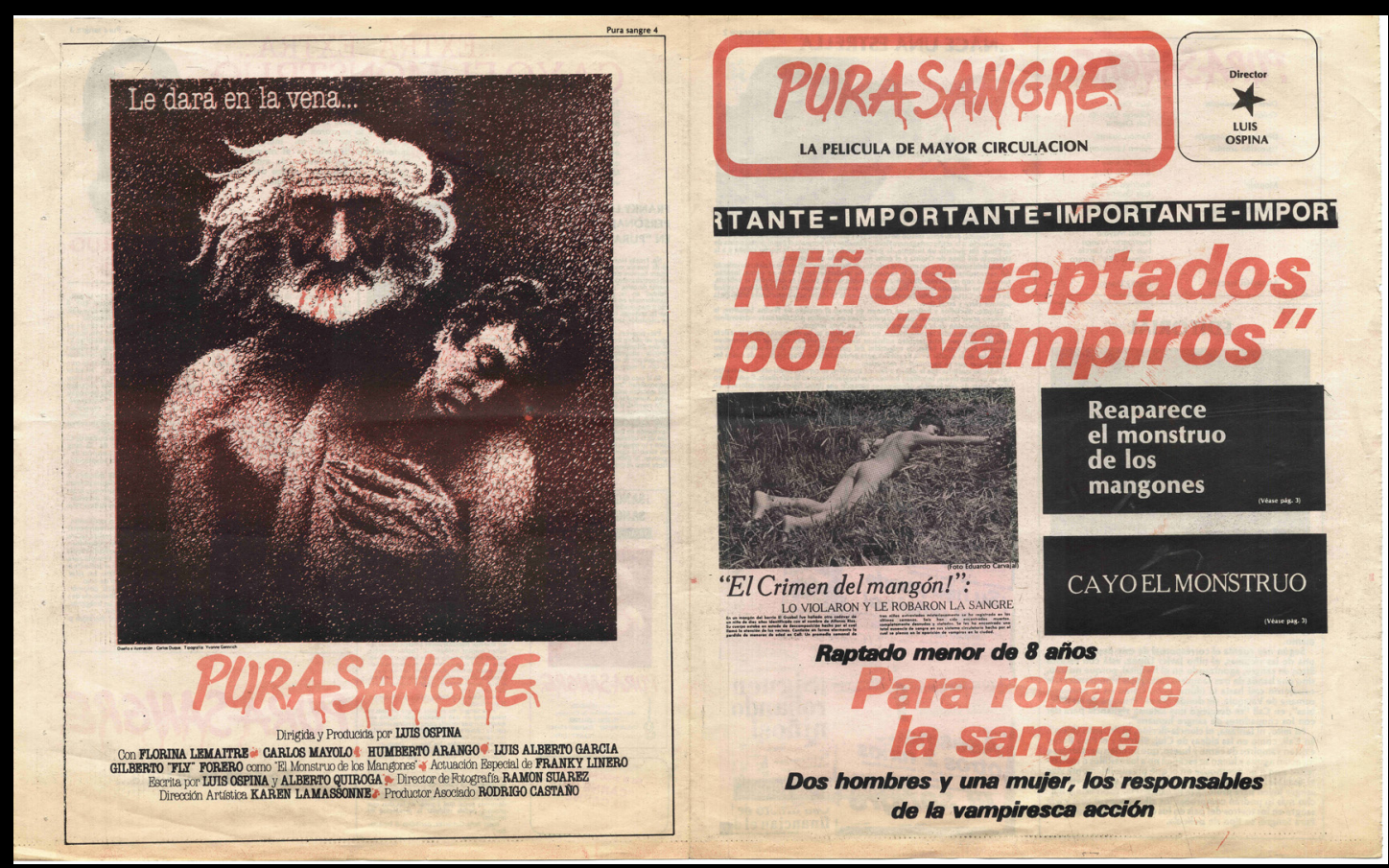

Crónica Roja, promotional material for Pure Blood (Luis Ospina, 1982). Source: Luis Ospina Personal Archive.

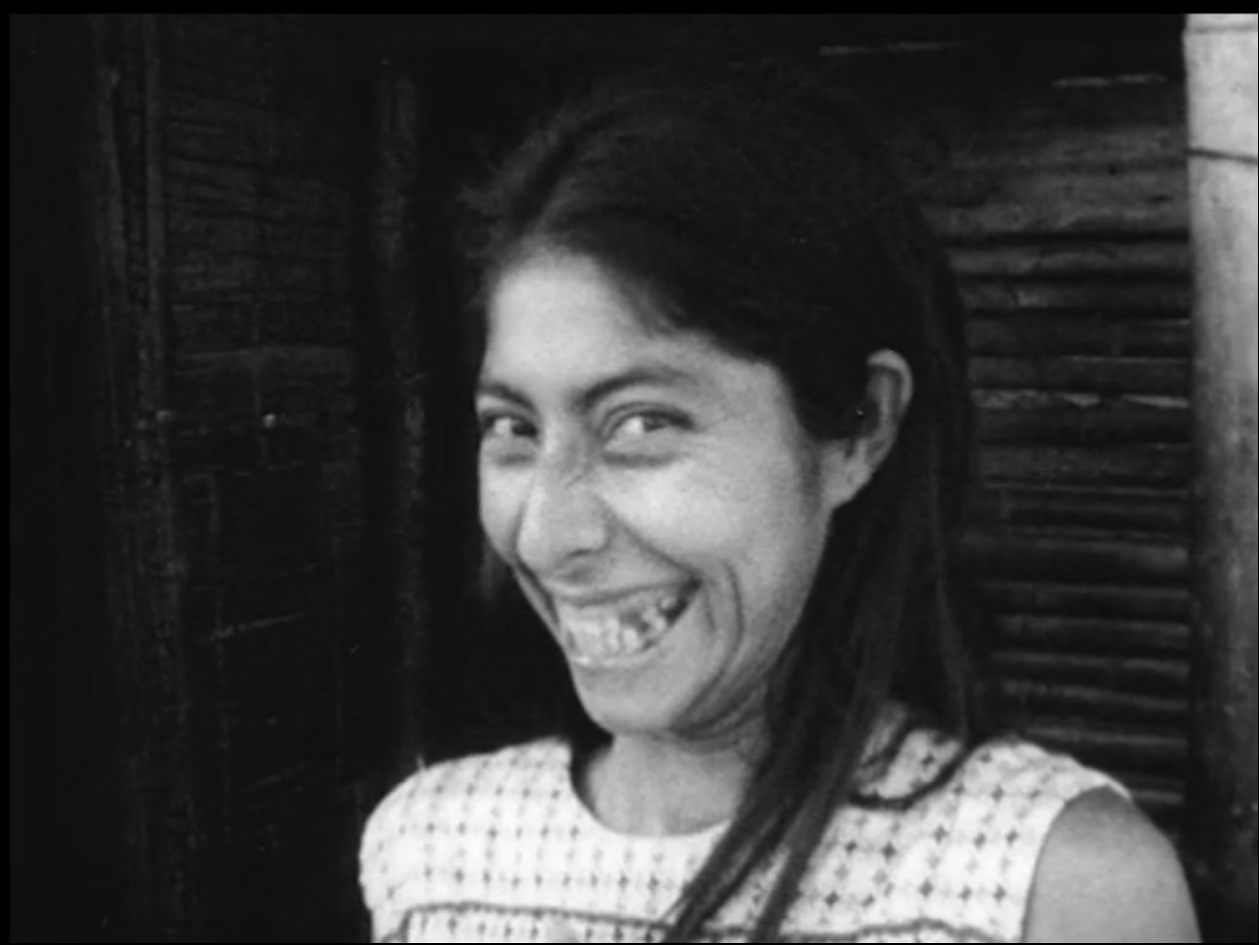

Listen, Look! (Carlos Mayolo and Luis Ospina, 1971)

\section{$\overline{2} \stackrel{m}{\circ}$ 임 sं}


I came upon a robbery at a branch of the Banco de Bogotá in Jiménez Avenue; one of the robbers was shot, I had my camera and I managed to get a photo of his bloody head... I probably still have it.

At some point I got some of the photos from the book on La Violencia, and a newspaper sold me some images under the table which I still have. These photos appear in some of my films, in The Supreme Uneasiness: Incessant Portrait of Fernando Vallejo (La desazón suprema: retrato incesante de Fernando Vallejo, 2003), and in Pure Blood, when the children are in Mayolo's photographic studio. I remember when I made the film about Fernando Vallejo, I told my friend Marta Elena Restrepo, head of the Caracol Television archives, that I wanted some atrocious images to illustrate Fernando Vallejo's atrocious speech, so she made me a compilation which we called Colombia Infame ("Infamous Colombia"). I had all kinds of atrocious images to choose from, it was like a tour of the dead through the history of Colombia. In the film on Vallejo I included images of the Bojayá massacre, images of the corpses; there are also pictures from my collection when we talk about La Violencia: a lady with a cross who says "they killed here" [the original is "acecinaron", with a writing mistake, instead of the correct "asesinaron"], and I mix photos from my collection with images from the archives I found in Caracol.

\section{The image of the corpse as a political trigger}

Both filmmakers brought up the image of Che Guevara's corpse. This photograph helps us to think about the strategies by which the images of the corpses of insurgents are turned into symbols, and how these circulate. We should also consider how cinema can reinterpret and transgress both the imaginaries that these symbols convey and the dynamics of commercialization that can be identified within such merchandise. With regard to the films made about the character of Camilo Torres, a revolutionary priest who joined the ELN (National Liberation Army) guerrilla in 1965 and was killed in his first combat a year later, Ramiro Arbeláez and Carlos Mayolo wrote in 1975: "the photo of the dead Camilo (issued by the UPI ${ }^{3}$ ) used in the film, together with that of the dead Che, used in The Hour of the Furnaces (La hora de los hornos, Fernando E. Solanas and Octavio Getino, 1968), are poignant examples of the mythification of death which lead to the minimization of the historical significance of the 
characters [...] Dealing with Camilo is a political problem which has no solution if he is mythicized or canonized but, on the contrary, only if we consider all of his revolutionary ideas, or we explore the permanence of his thinking as the correct weapon to apply to reality"'. In 1971 Mayolo and Ospina had already created a shot that responded to that image in The Hour of the Furnaces, specifically in Listen, Look! (;Oiga, Vea!, 1971), an explicitly political film that criticizes the elitist dynamics of the 1971 Pan American Games held in Cali.

\section{R}

Identifying the corpse with death can lead to erroneous interpretations, since it's hard to establish a difference between the two terms. I propose a distinction: the corpse points to a material problem, while death points to a questioning of thinking and imagination. The dead heroes who convey ideals are not the corpses of those leaders, because it is precisely the definitive disappearance of those men that opens up the perspective which sustains their ideals and tasks after them, creating a history of the country that we can imagine and wish for under different scenarios, but not live.

It is worth thinking, for example of Che Guevara's body, which everyone knows. Out of his corpse a material was forged: the photo of his corpse. This photo had the dual purpose of attesting to the death of the revolutionary man, and asserting antirevolutionary propaganda. It was thus necessary to establish forever the image of that corpse, so as to fix in our minds the supremacy of a capitalist world that allows no opposition. Since this is a problem of portrayal, we can easily situate it in the field of cinema by asking ourselves what cinema could express in opposition or counterbalance to this initial image imposed by Che's corpse.

The shot of the photo of the dead Che appears at the end of The Hour of the Furnaces, that eternal shot... the most extreme fanatics said that Che was resurrected in that photo [laughs]. Everyone sees what they want to see. In response to that shot, Carlos Mayolo and I made the final frame of Listen, Look!, the grimace by the Mona Lisa of underdevelopment, which was also the cover for the first issue of Ojo al Cine. In fact, I dated the origin for the Cali group, and it started in 1971, when we made that film. That year, the cinema club of Cali also began, Angelita and Miguel Ángel was made, Ciudad Solar was founded - in short, there were lots of events in that same year that were foundational for the group. Later, in the 1990s, at the end of the 

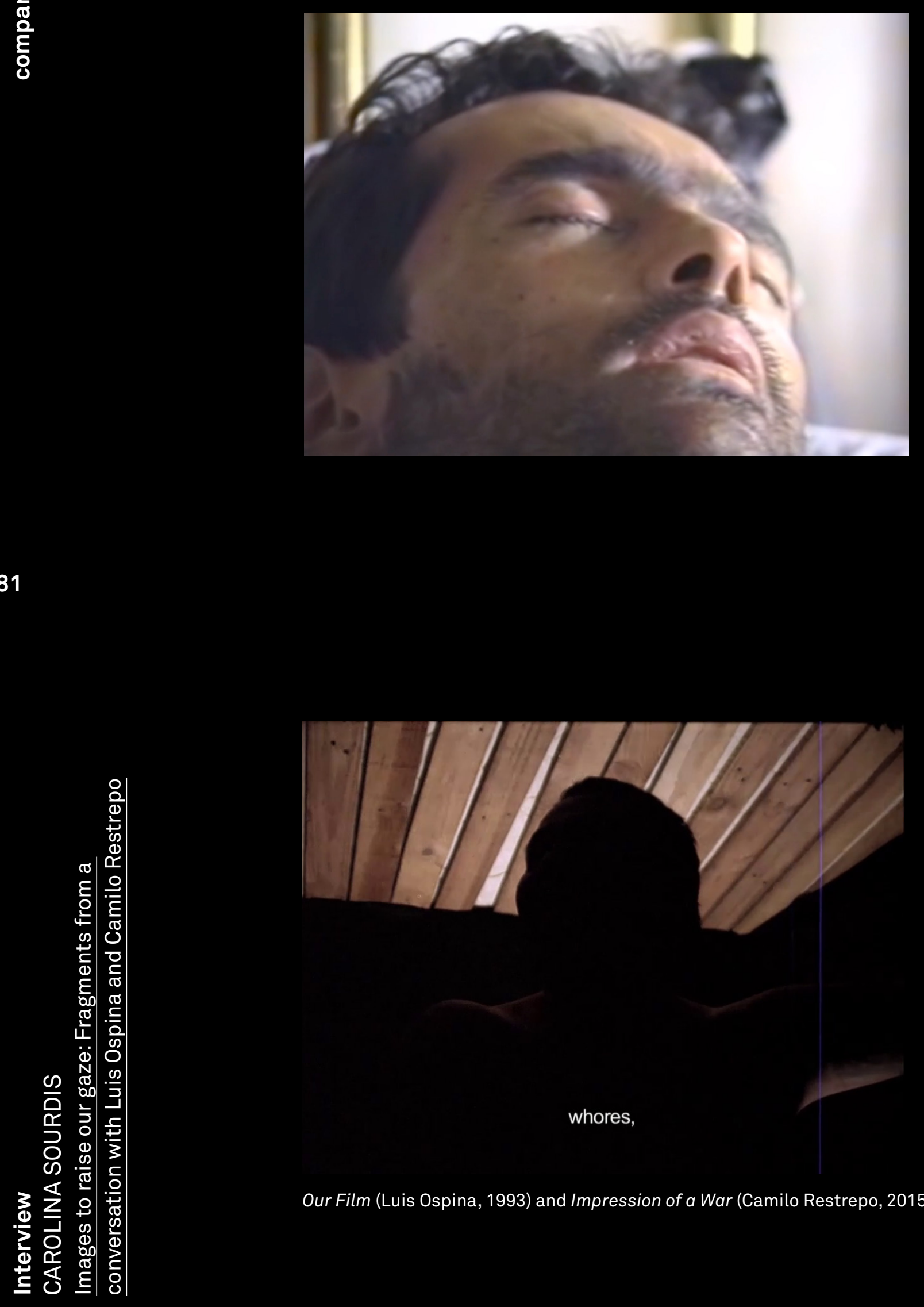

Our Film (Luis Ospina, 1993) and Impression of a War (Camilo Restrepo, 2015).

\section{$\bar{i} \stackrel{m}{\square}$ ì}


1980s, it was the time of drug trafficking in Cali, a great cultural decline, and the members of the group began their diaspora towards Bogotá.

\section{Watching/filming a decomposing body}

Records of the liberation of the concentration camps popularized the images of piled-up corpses, granting them a testimonial nature that somehow disguised their morbidity and rapaciousness. Their status as evidence of what happened, we suppose, succeeded in separating them from the obscene. This has determined both the way in which the corpses are represented in cinema, and the way we accept that representation: rarely do we find images of domestic or lost corpses from collective history. And when we regard these images of horror, our gaze is protected because it is testimonial proof, because we can recognize them as a vestige of a historical event that gives us a certain "right to see". However, as Susan Sontag rightly states, exhibiting images of suffering does not necessarily appeal to consciousness nor to the capacity for compassion; on the contrary, it can corrupt it. Those images, she claims, dumbfound, anesthetize, and even diminish the reality. Where is the limit when we film a dead body, its dehumanization, its decomposition? Where is the limit when we film a reality, whose visibility is so hard to sustain?

In Breath of Life (Soplo de vida, 1999), I work with images from the Armero tragedy. To make this film I had access to many private and television archives and I saw some terrible things. I remember the images of Omayra Sánchez, they are the most iconic images of someone dying, about to die, and they are closely linked to the audiovisual media because all the national and international journalists exploited the situation and kept taking photos and filming. There are even recordings where the girl, with her eyes already filled with blood, says to the reporters: "No more photographs, no photographs!" [originally in English]. It was a case where terrible agony met up with the mass media.

C R

Actually, I cannot imagine being interested in decomposing. But I must admit that Baudelaire's poem Une charogne is, without a doubt, a piece in which the image of a decomposing body is referred to masterfully and pertinently. The image of a corpse 
decomposing is something that is highly sensitive, in the sense that it comes too close to pornography. Baudelaire's readers know very well that Une charogne plays with this closeness. In the field of cinema, I prefer allusion to pornography.

I think it's interesting to construct the idea of death in cinema in that space we call off-camera. Interesting because doing it that way is somehow very logical. Isn't death already that off-camera of life, one that unceasingly calls our attention in terms of the scene we're living in?

L $0 \quad$ When I made Our Film (Nuestra película, 1993), in which I filmed the painter Lorenzo Jaramillo dying of AIDS, I edited out images from the last filming session, when he was already in the clinic in a state of delirium. I decided not to use those images; I literally felt like a pimp, a gallinazo (vulture)... How do they say it in Spain, like a buitre? When we filmed those images he wasn't in his right mind, he was hallucinating. For example, he'd say to me: "Luis, why don't you have a glass of wine?" I'd reply: “Lorenzo, where's the wine?", and he'd say: "Right there, on the table"; but of course, it wasn't. I didn't film his death literally, but it was very close, I think. Before shooting that film I saw lots of others about AIDS, and it bothered me a little that sometimes the people who were being filmed didn't look too good. But I think that throughout my whole film Lorenzo looks very handsome; he doesn't look like he's in a state of terminal illness, like in other films about AIDS that were made at that time. And there's an agreement that you make with the person who is dying: whether they agree to be filmed in that state or not. Before I filmed him I wasn't really a friend of his, I was more a friend of his sister; I had met him once in Paris and we got along very well. I met him again at the screening of an Andy Warhol movie at the Museum of Modern Art in Bogotá, and later on he asked me for my film about Andrés Caicedo to show it to his students at the Universidad de los Andes. So I met him three times, and then through his sister I answered his call: he was willing to let me film him. That was, in fact, the first film that addressed the issue of AIDS in Colombia. At the beginning of the film I make an agreement with Lorenzo, and then I ask him again if he's upset that I am filming, and he replies that he doesn't care if there are 100 cameras, all he cares about is saying what he has to say.

In It All Started at the End I filmed another decomposing body - mine, which wasn't in the original project, because I got sick on the first day of the shooting. The film was supposed to be 
different, but when I saw that my own body was the one that was weakening I decided to put modesty aside a little and make it openly autobiographical - to show myself in the grimmest way possible. I had seen a film that had made a great impact on me: Sick: The Life and Death of Bob Flanagan, Supermasochist (1997), by Kyrby Dick, and by the way, when I watched it almost everyone else left the movie theatre. It's about a guy who allows himself to be filmed until his death, a sadomasochistic artist who marries a sadist; she works with his body and subjects him to all kinds of tortures that he enjoys. He allows himself to be hung on hooks, the woman takes all the fluids that come out of his body and puts them in bottles... it's a very peculiar relationship. For me, this film managed to break the barrier that exists between body and disease, because he suffers from a degenerative illness and that is documented until he practically dies. When I decided that I, myself, was going to film my illness and that others were going to film my sick body, I thought I had to break the barriers of modesty. I am shown naked, in a state of complete vulnerability.

I saw Mayolo's body. As soon as he died, his partner Beatriz Caballero called me and I went over to his place. Several friends and I went to help, to see what we could do, the paperwork when someone dies, the announcement in the press, and amidst all that I got to see him. He's the closest friend I've seen dead, I even touched him, I had that urge to touch him, I held his hand.

When I made It All Started at the End I found an image of him sitting down, asleep in the same armchair in which he died, because Mayolo died like a Swiss banker, reading the newspaper El Siglo. Beatriz was in the next room and didn't hear him, she explains this very well in the film. It's not an image that I've filmed, I took it from a film that Roberto Triana made about Mayolo (Mayolo de película ["Mayolo, like in the movies"], 2006) where he falls asleep. I hesitated a lot before putting it in that exact moment, when Beatriz recounts the whole sequence of events of the day Mayolo died, because it was along the lines of "Shit, they filmed the guy dying", but let's just say that it was poetic license that I felt was well justified, and some people think I really filmed the corpse. 


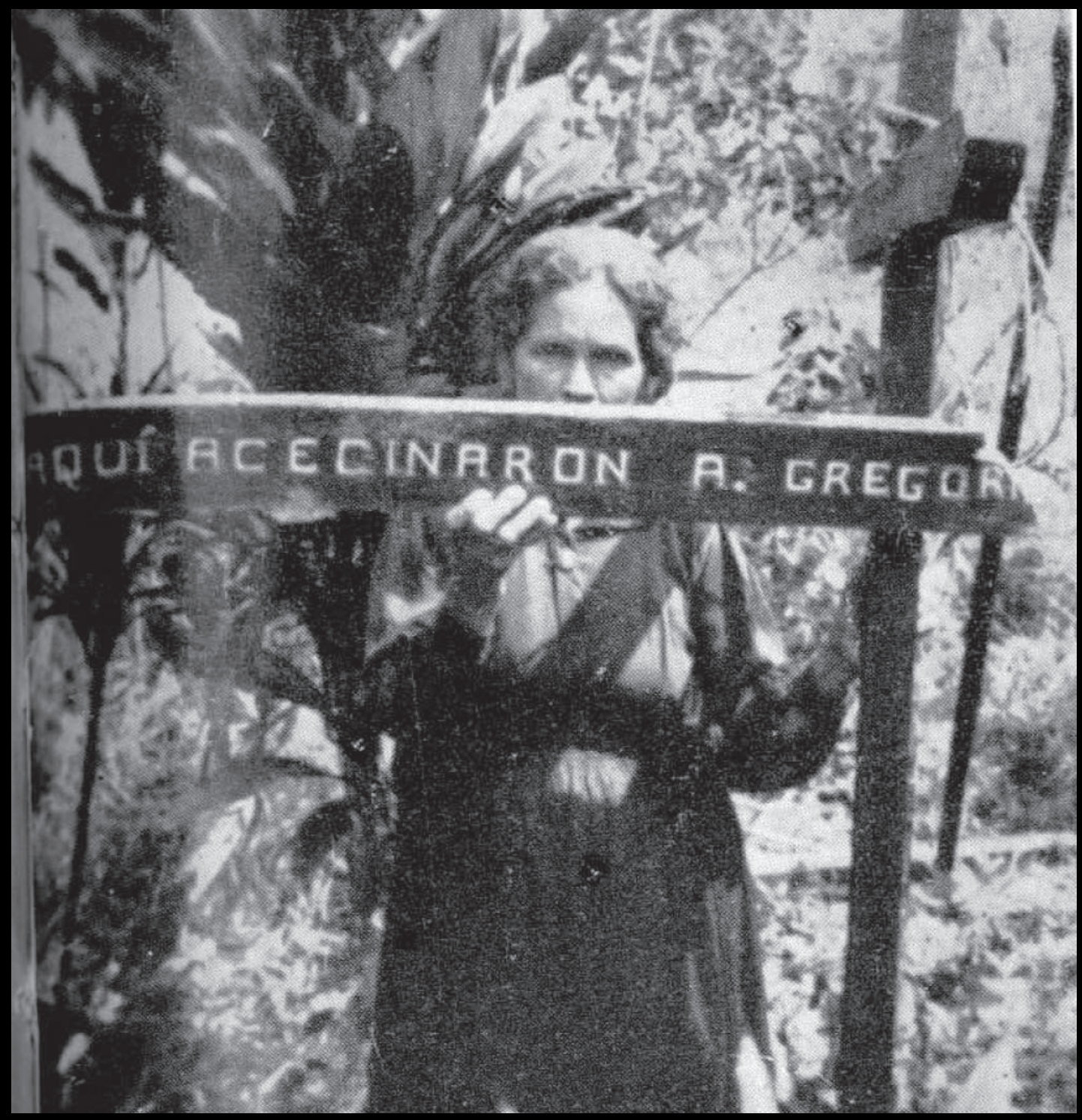

Author: unknown. Source: La Violencia en Colombia (Orlando Fals Borda, Germán Guzmán Campos, Camilo Torres Restrepo, Eduardo Umaña Luna, 1962-1963).

\section{$\bar{m} \stackrel{0}{\circ}$ $\dot{s} \dot{2}$}




\title{
Images to project a feature of humanity
}

\begin{abstract}
Orlando Fals Borda, one of the pioneers of sociology in Colombia who examined the period of La Violencia noted in 1960:

"Wouldn't it be masochistic to ruminate on the dreadful issues of political violence (just one of the social consequences of hatred), repeating its lugubrious details, recalling torture and outrage, digging down into the bloody dust of the massacres or the nauseating mud of political detritus, without looking up to discover some light, some hope of relief or salvation?". ${ }^{\text {Almost }}$ 60 years later, amidst the saturation of images and narratives of the longest armed conflict in Latin America, and at the rise of civil support for warmongering policies, can that vast and terrifying pile of images of "our" dead bodies indicate something about the uniqueness of the historical event? Could the image of a corpse in Colombia refer to something other than hatred, evil or violence?
\end{abstract}

Translated by Daniela Torres Montenegro

(See original texts at the end of the journal)

1/ The questionnaire included the following questions: Sometimes in order to better portray a mountain, to get the measure of its scale, we need a human figure: is a living figure necessary when filming a corpse? Antigone believes that the unburied corpse of Polynices will not only contaminate the soil, but also the whole horizon of Thebes. How to shoot the decomposition of a corpse; would it be of any interest to do so? In The Trouble with Harry (1955), Hitchcock doesn't let his characters have any peace until they get rid of the corpse. Can there be comedy with a corpse? What would a corpse allow that a living body wouldn't? What would its social role be? Some prototypical corpses in cinema are associated with the imaginary of their times: Frankenstein with the frantic deliriums of science, zombies with the period in which AIDS spread... What do the excessive numbers of corpses in Colombia indicate? Were the "False positives" the best, the worst and the most macabre staging of corpses in Colombia? What trait of humanity endures longest in a corpse? Reflecting on the murder of Camilo Torres, in Francisco Norden's film Camilo, el cura guerrillero ("Camilo, the guerrilla priest", 1974), García Márquez claims that in Latin America we only believe in dead heroes. The leaders of the popular political projects in Colombia have been murdered: Gaitán, the leaders of the UP (Patriotic Union), Galán, the social leaders... What do these corpses say about us and what could cinema express about them? In November 1985 the Nevado del Ruiz erupted. The tragedy left us with the live broadcast of a death. Omayra Sánchez, 13, who was buried in the rubble, could not be rescued, and died in front of the cameras. That same month there was the occupation of the palace by the M-19 (April 19 Movement). How can you link these two images?

2/ La Violencia refers to the historical period in Colombia from 1948 to 1958 in which several confrontations between members of the Conservative and the Liberal Party were produced. It was triggered by the murder of populist leader and Liberal presi- 
dential candidate Jorge Eliécer Gaitán on 9th April 1948. This period featured atrocious crimes between both sides and the forced displacement of millions of peasants to the cities.

3/ United Press International.

4/ See ARBELÁEZ and MAYOLO, 1975.

5/ Orlando Fals Borda (1960) in Soluciones sociales para los problemas del odio y la violencia. Actualidad Cristiana, year V, n. 20, p. 94. Quoted in La Violencia en Colombia ("Violence in Colombia", FALS BORDA; GUZMÁN CAMPOS; TORRES RESTREPO; UMAÑA LUNA, 2005: 225).

\section{Bibliography}

ARBELÁEZ, Ramiro; MAYOLO, Carlos (1975). Camilo, el cura guerrillero. Ojo al Cine, n. 2, pp. 80-83. Retrieved from: https://www.luisospina.com/archivo/ grupo-de-cali/revista-ojo-al-cine/ [access: May 6th 2019]

FALS BORDA, Orlando; GUZMÁN CAMPOS, Germán; TORRES RESTREPO, Camilo; UMAÑA LUNA, Eduardo (2005) [1962-1963]. La Violencia en Colombia (volumes I and II). Bogotá: Taurus. 
En esta conversación, Luis Ospina y Camilo Restrepo, dos cineastas que encarnan dos tiempos del cine y la historia colombiana, reflexionan sobre la presencia del cuerpo muerto en el cine y, particularmente, sobre el cadáver como materia fílmica en sus respectivas obras y poéticas. Partiendo de un cuestionario similar realizado en paralelo con cada cineasta, el texto recoge motivos comunes y disonantes para esbozar un posible arco generacional del cine colombiano donde la representación cinematográfica del cadáver se propone como motivo historiográfico y político para hacer una lectura del cine y la historia.

\author{
Palabras Claves \\ CADÁVER \\ HISTORIA \\ MEMORIA \\ CINE COLOMBIANO \\ VIOLENCIA \\ VIOLENCIA BIPARTIDISTA \\ FALSOS POSITIVOS \\ CONFLICTO ARMADO COLOMBIANO \\ Fecha de recepción: 15/10/2018 \\ Fecha de aceptación: 06/05/2019
}

Luis Ospina (Cali, Colombia, 1949 - Bogotá, Colombia, 2019) Cineasta. Cofundador, junto con Andrés Caicedo, Carlos Mayolo y Ramiro Arbeláez, de la revista Ojo al Cine (1974-77). Dirigió más de 40 películas, entre largometrajes, documentales y piezas de videoarte. Guionista y director de la película Pura sangre (1982), y co-director, junto a Carlos Mayolo, de Agarrando pueblo (1977). Editor de los largometrajes Carne de tu carne (1983) y La mansión de Araucaíma (1986) de Carlos Mayolo, entre otros. Desde 2009 hasta su fallecimiento fue Director Artístico del Festival Internacional de Cine de Cali.

Camilo Restrepo (Medellín, Colombia, 1975) Desde 1999 vive y trabaja en París. Es miembro de L'Abominable, laboratorio independiente de cineastas trabajando en celuloide. Su filmografía cuenta con cuatro cortometrajes, de los que se destacan La impresión de una guerra (2015) y Cilaos (2016), ambos ganadores del Pardino d'Argento en el Festival Internacional de Cine de Locarno. La impresión de una guerra ha ganado además siete otras recompensas en festivales.

Carolina Sourdis Doctora en Estudios de Cine por la Universitat Pompeu Fabra donde es profesora asociada. Sus piezas visuales han sido exhibidas en festivales en España, Colombia e Irán. Ha contribuido en el libro Archivo, memoria y presente en el cine lationamericano y publicado artículos en varias revistas como Cuadernos del Cine Colombiano, Cinema Comparat/ive Cinema o New Cinemas: Journal of Contemporary Film. 
No. No vinimos a este mundo a quedarnos. Vinimos a pasar como el viento y a morir. A veces ese viento al pasar hace estragos y tiene nombre: se llama Pablo Escobar, se llama Miguel Rodríguez Orejuela, se llama Carlos Castaño, se llama Tirofijo, se llama Gaviria, se llama Samper, se llama Pastrana.

Aprendan mientras se van a ponerle nombres propios a la infamia.

A los muchachos de Colombia, Fernando Vallejo

En esta conversación, Luis Ospina y Camilo Restrepo, dos cineastas que encarnan dos tiempos del cine y la historia colombiana, reflexionan sobre la presencia del cuerpo muerto en el cine y, particularmente, sobre el cadáver como materia fílmica en sus respectivas obras y poéticas. Así, partiendo de un cuestionario similar realizado en paralelo ${ }^{1}$, la disposición de estos fragmentos de entrevista pretende recoger motivos comunes y disonantes para esbozar un posible arco generacional del cine colombiano. En él, la representación cinematográfica del cadáver permitiría señalar y desmembrar las capas de un real -mercenario, violento, atroz; cínicamente cíclico por ser historia y presente a la vez- que desborda todos los contornos de lo imaginable.

Esta conversación, pues, no es tal en sentido estricto: las preguntas y anotaciones formuladas como motor de cada motivo a lo largo del texto surgen a posteriori, en la puesta en relación de las reflexiones de Ospina (LO) y Restrepo (CR) tras un ejercicio de descomposición y montaje de sus respuestas frente un cuestionario clásico. Es, más bien, un contacto virtual entre los cineastas y sus ideas -también entre las preguntas y respuestas del texto- para plantear relaciones posibles entre la muerte y el cuerpo, la memoria y la historia a partir de las imágenes del cadáver en el cine.

* La entrevista con Luis Ospina fue realizada en su apartamento en Bogotá en verano de 2018. En la entrevista nos regaló una copia que guardaba de Crónica Roja, el periódico que circuló como promoción de Pura sangre en 1982. Y nos regaló muchísimo tiempo, con la generosidad de siempre, con su tremenda humildad, su genial humor negro. Luis alcanzó a revisar esta conversación en el formato aquí publicado, y nos hizo llegar las imágenes de su propio archivo que, para él, la acompañaban mejor. Murió poco antes de la publicación de este número, el 27 de septiembre de 2019. Gracias Luis. 


\section{Los ciclos de la violencia en Colombia}

A lo largo de su historia, el cine colombiano ha abordado de manera enfática la representación del llamado periodo de La Violencia ${ }^{2}$, además de otros tipos de violencia relacionados con el conflicto armado y las consecuencias sociales y políticas de la guerra: El río de las tumbas (Julio Luzardo, 1964), Cóndores no entierran todos los días (Francisco Norden, 1984), Confesión a Laura (Jaime Osorio, 1990), para nombrar algunas. ¿Podrían las imágenes del cuerpo muerto surgir a la vez como motivo visual, político e historiográfico a lo largo de esa historia?

L 0 Cuando se hizo ese gran ciclo de cine colombiano en la recién inaugurada Cinemateca Distrital en Bogotá -un ciclo que fue, para mí, el primer ciclo grande que se hizo en Colombia de cine colombiano-, pude ver, quizá, la primera película de ficción que tocó el tema de La Violencia, un cortometraje que se llamaba Esta fue mi vereda (Gonzalo Canal Ramírez, 1959). Entre todas esas películas había otras como Aquileo venganza (Ciro Durán, 1968), una especie de western colombiano; y las películas políticas de esa época, que siempre tocan temas de violencia, como Camilo Torres de Diego León Giraldo (1966), que se hizo casi inmediatamente después de la muerte de Camilo Torres, una película muy urgente. De hecho, una de las imágenes de cadáveres que más recuerdo es precisamente ésa, la del cadáver de Camilo, la uso en mi película Un tigre de papel (2007). Pero es que en Colombia hay tantos muertos... Para mí, las imágenes más impactantes de cadáveres son las imágenes de la violencia bipartidista, ver hasta qué grado de sofisticación se llegó, cómo mataban a la gente. Hay esta teoría que dice que, en la época de La Violencia, esta gente mataba tanto y de tal forma, que iban sofisticando los mecanismos de muerte para que la persona recordara, en la otra vida, cuánto sufrió antes de morir: ¡Querían castigar a la gente hasta la otra vida! Hacían las cosas más atroces. Esto encuentra un paralelo muchos años después con los paramilitares, con situaciones terribles: cuando jugaban fútbol con las cabezas de la gente o con los "falsos positivos». Aunque yo nunca he tocado el tema de los paramilitares porque me he ocupado de otras épocas. Llego hasta el siglo pasado.

C R En el contexto colombiano no creo que haya que ir a buscar muy lejos el imaginario que podrían representar las imágenes excesivas de los cadáveres: la amenaza constante de vivir en una sociedad regida por la ley del más fuerte, sumida en el caos 
general y la injusticia banalizada. El Madmax colombiano, para ponerlo en términos claros. Un imaginario que no es más que la proyección (exacerbada, o quizás no...) de la vida cotidiana de muchos colombianos. El poeta Gonzalo Arango vaticinó la resurrección de los grandes bandidos de la época denominada La Violencia empleando términos de «muertos-vivientes». Su poema Elegía a Desquite termina así: «¿No habrá manera de que Colombia, en vez de matar a sus hijos, los haga dignos de vivir? Si Colombia no puede responder a esta pregunta, entonces profetizo una desgracia: Desquite resucitará, y la tierra se volverá a regar de sangre, dolor y lágrimas».

Desquite, es, de hecho, un personaje que aparecerá en mi próxima película. Nacido en 1936 en hogar campesino, esposó las armas a los 14 años después de sufrir varias injusticias. Intentó sin éxito integrarse al ejército y luego a la vida civil, pero parece que su destino era el de bandido. Encarnó la figura del buen bandido, una suerte de Robin Hood entre ladrón y guerrillero. Pero en realidad no fue siempre bueno, sabía ser despiadado y cruel, como el gobierno en esa época. Cuando el ejército logró matarlo en 1964, se exhibió su cadáver en la plaza pública de varios municipios para que el pueblo entendiera "cómo se derrumbaba el imperio de los bandoleros". Pero como dijo Gonzalo Arango, Desquite se desquitará de nuevo, porque el imperio de los bandoleros no se ha derrumbado aún, porque los gobiernos de bandoleros no se han acabado aún.

\section{De la prueba documental a la figuración del cadáver}

El acervo de imágenes documentales de atentados, masacres y asesinatos cometidos en territorio nacional por grupos insurgentes, paraestatales o relacionados con el narcotráfico desafía cualquier imaginario de maldad posible: la realidad excede cualquier noción de barbarie. Por otra parte, las imágenes están expuestas, son transmitidas por medios masivos de información, consumidas por una audiencia, son imágenes conocidas y de alguna manera asumidas. ¿Cómo transformar la prueba documental del desastre en una imagen que logre interpelar a una mirada anestesiada? ¿Cómo convertir una imagen testimonial en el germen de una materia fílmica? ¿De qué forma las imágenes del horror han determinado los imaginarios para representar el cuerpo en el cine colombiano?

La primera imagen de un cadáver que vi fue en la colección de revistas Life que tenía mi padre. Él había empastado todas las revistas Life de fines de los treinta, todo el periodo de la 
guerra hasta ese momento, que era principios de los sesenta. Ahí recuerdo haber visto cadáveres de la Segunda Guerra Mundial, me impresionaron mucho sobre todo las fotos de los cadáveres del desembarco de Normandía. Creo que ya las primeras imágenes de cadáveres colombianos que vi fueron las que venían en los periódicos de Cali en ese momento, El Relator y El País. A menudo, uno veía en el periódico esas imágenes de pilas de cadáveres, de gente degollada con esos métodos tan sofisticados que tenían los bandoleros de la época, con el corte de corbata, el corte del chaleco, los decapitados... En fin, todos los que crecimos en esa época vimos esas imágenes horrendas. Posteriormente, salió el libro de La Violencia en Colombia, de Monseñor Guzmán Campos, Orlando Fals Borda y Eduardo Umaña Luna, casi todas las casas en Colombia lo tenían. Era un libro desde luego sobre la violencia con $V$ mayúscula, sobre la pelea bipartidista entre liberales y conservadores. El libro tenía fotos, me marcaron muchísimo; sé que a Carlos Mayolo también porque crecimos más o menos en un mismo medio y una misma época.

Otras imágenes que me marcaron fueron las de los cadáveres ya mutilados y destrozados por la explosión del 7 de agosto de 1956 en Cali, cuando tenía 7 años. Fue una famosa explosión que no ha dejado calcular sus muertos. Las cifras más altas apuntan 3 mil y de ahí se cuenta para abajo. Esta explosión se dio porque el gobierno de Rojas Pinilla llevó una carga de dinamita desde Buenaventura a Cali, y parquearon la docena de camiones cargados en lo que era llamado la zona roja, la zona de tolerancia. Nunca se pudo saber por qué explotó, pero como a la una de la mañana el camión creó una onda explosiva grandísima que destruyó parte de mi casa. Por eso tuvimos que mudarnos a donde mi abuela, al frente de donde vivía Mayolo.

Mi mamá hacía voluntariado en el sitio de la tragedia y ella nos contaba las historias escabrosas de cómo la gente comenzó a mutilar los cadáveres para robarse los anillos, para saquearlos, eso fue terrible. Y otra cosa terrible fue que como la explosión se dio cerca al cementerio central, la tumbas eyectaron los muertos que estaban sepultados con la onda explosiva. Yo encontré un noticiero en Patrimonio Fílmico que se llama Tragedia en Cali, sale en dos películas mías: en Todo comenzó por el fin (2015) y en la serie Cali, ayer hoy y mañana (1995). Es un material muy bien filmado por un señor que se llamaba Ramón Carthy, venezolano, y es como un pequeño documental de lo que pasó el 7 de agosto de 1956. Sobre ese evento Mayolo hizo Carne de tu carne (1983), utilizó ese momento histórico 
preciso para situar la historia del incesto.

Por otra parte, también viví de cerca la guerra de Vietnam, de alguna manera. Yo estudiaba en Estados Unidos en esa época. Hay dos imágenes que filman la muerte que uno no puede olvidar, una es la de un oficial vietnamita que mata a un Viet Cong, le pega un tiro, eso está filmado; y la imagen de la niña desnuda quemada por el Napalm. De la Guerra Civil Española está el emblemático plano de Robert Capa en donde se ve que le disparan en la cabeza. Por cierto, hay toda una corriente de pensamiento que dice que esa foto es trucada y que no se tomó en ese sitio, y es un desinfle pensar que esa, tal vez la imagen más icónica de la Guerra Civil Española, sea una puesta en escena. Pero ahí se entra en el terreno de cómo se escenifica la muerte, o cómo se puede falsear. En eso también podríamos irnos a los inicios del cine colombiano, a esa película desaparecida, El drama del 15 de Octubre (Franceso Di Domenico, 1915), en donde hay un crimen real, el de Rafael Uribe Uribe, y los asesinos hacen el papel en la película, se pone en escena y se falsea la realidad metiendo planos de otros entierros.

Otras de las imágenes en movimiento más impactantes son las escenas en las que arrastran a Roa Sierra, el asesino de Jorge Eliécer Gaitán, desnudo, por la carrera séptima. Las utilizo en Un tigre de papel; también salen en la película Confesión a Laura de Jaime Osorio, y en muchas películas colombianas y extranjeras. Es muy parecida a las imágenes de los cadáveres de Mussolini y Clara Petacci, cuando los mataron y los desnudaron.

Me parece que de un trabajo a otro en mis películas he ido abandonando el cadáver para ocuparme más de la muerte. Dicho en otros términos: abandonando el hecho concreto para perderme en la abstracción de la idea. Intento resumir en pocas palabras este trayecto.

En mis primeros cortos la formulación fue la siguiente: ¿Acaso el examen de una muerte en particular puede arrojar una luz de comprensión frente al cortejo de millones de muertos de una guerra? El cuestionamiento apuntaba a la problemática del conflicto armado colombiano y a las diferentes violencias civiles y políticas que han acompañado dicho conflicto. Esta pregunta por supuesto no es válida sin su corolario: ¿La manera en que se muere en una sociedad puede dar a entender la manera en que se vive en dicha sociedad? Porque, al fin de cuentas, pensar en 
la muerte solo tiene sentido si se piensa para vivir.

Bajo estas dos interrogaciones traté, entre otros hechos, la masacre denominada de los «falsos positivos». Personas asesinadas por el ejército colombiano bajo una puesta en escena en la que los militares disfrazaban de guerrilleros a civiles (antes o después de asesinarlos) con el propósito de alimentar las estadísticas de «muertos en combate» que legitimaban la labor del gobierno contra la guerrilla. La manipulación de la información (propaganda sobre el supuesto éxito del combate antiguerrilla), partía de una manipulación física de los cadáveres al ser disfrazados de guerrilleros en el lugar de la masacre. Precisamente la puesta en escena y la verdad de los hechos se descubrió porque la manipulación fue inexacta y tratada con ligereza en el terreno (botas puestas al revés, para dar un ejemplo entre otros). En los hechos, los militares grababan con sus teléfonos los cadáveres para que las imágenes sirvieran así de prueba del éxito de su labor. Por otro lado, esos mismos militares con esos mismos teléfonos filmaban sus propios momentos de ocio y de descanso, creando así el contraste de sus alegrías recreativas y de sus labores asesinas. La imagen del militar en euforia permitía considerar la distancia que le separaba del cadáver que dejaba atrás.

En mi película La impresión de una guerra (2015) confronté los cadáveres de civiles muertos a otro tipo de «naturalezas muertas", para hablar en términos de representación. Consideré entonces el cadáver como un objeto entre otros objetos. Como objeto, el cadáver se presta a la manipulación, en el sentido más amplio de la palabra. La manipulación de ese objeto/cadáver fue precisamente uno de los puntos de partida de mi análisis empírico del conflicto armado colombiano y de sus diferentes violencias civiles y políticas.

Ya en mis últimos cortos dejé de considerar la imagen del cadáver, pasando a filmar personajes vivos que se pasean por la muerte, conversan y cantan con los muertos. Una posible razón de ese cambio sería la siguiente: frente al cadáver nosotros mismos debemos hablar por él, y yo, desde hace ya un tiempo, quería que el mensaje de los muertos viniera enunciado por ellos mismos, con sus propias palabras y bocas. Fue así como decidí abordar la ficción: frente a la inmensidad de la muerte como espacio de imaginación, y no más frente al detalle del cadáver como prueba documental.

Ya el primer cadáver físico que vi fue a cuadra y media de mi casa, cuando tenía más o menos entre trece y catorce años. Vi una aglomeración en un terreno baldío que en Cali le llamamos 
mangones, y me asomé a ver qué era lo que estaba pasando. Había un cadáver de un niño desnudo e inflado. Esa era la época del famoso asesino serial "el Monstruo de los Mangones», que mató en total a unos trece niños; los violaba, a veces aparecían con un hueco en el corazón. La imaginación popular empezó a crear un mito urbano sobre quién podía ser ese monstruo, y decían que esos niños eran víctimas a las que se les sacaba la sangre, porque había un señor muy rico en Cali que tenía una extraña enfermedad para la que necesitaba sangre de niño. Era una época de terror, a uno le decían «iNo salga a la calle, no después de tantas horas!», porque uno podía caer en las manos de ese monstruo. Ese fue el primer cadáver que vi, impresionante también porque era un chico, tal vez menor que yo. Eso me impactó muchísimo. Este mito urbano es el que yo luego usé para hacer la película Pura sangre (1982).

En esa película recreo la escena en donde vi a ese primer cadáver. De hecho, en uno de los periódicos que hicimos para la promoción de la película, Crónica Roja, sale esa recreación. Repartíamos ese periódico personalmente en la calle cuando salió la película y pusimos también la historia del monstruo, cómo se relaciona con Drácula. Aparece también Babalú, que es este personaje negro, demente, con los ojos siempre desorbitados, que se adjudica los muertos del «Monstruo de los Mangones» al final de la película. Él era en realidad un tramoyista, no era actor. El discurso que interpreta lo saqué de un reportaje que vi sobre el Monstruo de los Andes, y otra parte la tomé de un loco famoso de Cali, marihuanero, amigo mío que sufría del síndrome de Tourette y decía toda clase de barbaridades. Se llamaba el loco Guerra, por ahí lo tengo hasta en cerámica, era un personaje típico, un loco típico de Cali. Le daban unos ataques de rabia tenaces y tenía un discurso muy agresivo, entonces yo agarré esos dos textos y los mezclé. Estuve ensayando a este tipo casi tres meses, hasta que logré lo que quería. En la realidad nunca capturaron al asesino, los crímenes del «Monstruo de los Mangones» quedaron impunes. Creo que la muerte es una obsesión que he tenido desde niño, tal vez, precisamente por haber crecido en esa época de los años cincuenta, donde la muerte estaba en primera página. Tengo mi colección de muertos, incluye una colección pequeña de fotos de La Violencia colombiana, de la época de los años cincuenta, entre otras cosas. La primera imagen de esa colección la tomé en Bogotá, me crucé con un asalto bancario a un Banco de Bogotá que estaba en la Avenida Jiménez, a uno de los asaltantes le pegaron un tiro, yo iba con mi cámara 
fotográfica y alcancé a tomar una foto de la cabeza de él, sangrante... Creo que la debo de tener todavía.

En algún momento ya conseguí algunas fotos del libro sobre La Violencia, y por debajo de cuerda en algún periódico me vendieron unas imágenes que también guardo. Esas imágenes salen en algunas de mis películas, en La desazón suprema: retrato incesante de Fernando Vallejo (2003), en Pura sangre cuando están los niños en el estudio fotográfico de Mayolo. Recuerdo que cuando hice la película de Fernando Vallejo, le dije a mi amiga Marta Elena Restrepo, jefa del archivo de Caracol, que yo quería imágenes atroces para ilustrar el discurso atroz de Fernando Vallejo, entonces ella me hizo una recopilación que llamamos en ese momento Colombia Infame; tenía para escoger todo tipo de imágenes atroces. Eso era como un recorrido de los muertos en la historia de Colombia. En la película de Vallejo incluí imágenes de la masacre de Bojayá, imágenes de los cadáveres; también hay fotos de mi colección cuando se habla de La Violencia: una señora con una cruz que dice «aquí acecinaron», asesinaron con doble c, mezclo fotos de mi colección con imágenes de los archivos que encontré en Caracol.

\section{La imagen del cadáver como detonante político}

Ambos cineastas trajeron a colación la imagen del cadáver del Che Guevara. A partir de ella, cabe preguntarse por las estrategias con las que las imágenes de los cadáveres insurgentes son convertidas en símbolos y en cómo circulan. Habría que detenerse, además, en cómo el cine puede reinterpretar y transgredir tanto los imaginarios que portan esos símbolos, como las dinámicas de comercialización que se pueden rastrear en esas mercancías. A propósito de las películas que se producían alrededor de la figura de Camilo Torres, sacerdote revolucionario que se unió a la guerrilla del ELN en 1965 y fue abatido en su primer combate un año después, Ramiro Arbeláez y Carlos Mayolo escribían en 1975: "La foto de Camilo-muerto (difundida por la UPI ${ }^{3}$ ) usada en la película, junto con la del Che-muerto, utilizada en La hora de los hornos, son ejemplos patéticos de la mitificación de la muerte, de lo que resulta la minimización del curso histórico de los personajes [...] Enfrentarse a Camilo es un problema político cuya solución no se da cuando se lo mitifica o canoniza, sino, por el contrario, en la medida en que se recoja su pensamiento revolucionario, en la medida en que se explore la permanencia de su pensamiento como arma correcta para aplicar a la 
realidad»4. Ya en 1971 Mayolo y Ospina habían hecho un plano que contestaba a esa imagen de La hora de los hornos, justamente en ¡Oiga, Vea! (1971), un filme explícitamente político en el que se critican las dinámicas elitistas de los Juegos Panamericanos del 71 celebrados en Cali.

C R La identificación entre cadáver y muerte puede conducir a interpretaciones erróneas, pues es difícil establecer la diferencia entre ambos términos. Propongo una distinción: el cadáver apunta a un problema material, mientras que la muerte apunta a un cuestionamiento del pensamiento y de la imaginación. Los héroes muertos que vehiculan ideales no son los cadáveres de esos líderes. Pues precisamente la desaparición definitiva de esos hombres abre la perspectiva que prolonga sus ideales y labores más allá de ellos, dibujando una historia del país que podemos imaginar y desear bajo diferentes escenarios, pero no vivir.

Vale la pena pensar por ejemplo en el cadáver del Che Guevara, que todo el mundo conoce. Del cadáver del Che se forjó un material: la foto de su cadáver. Esta foto tenía como doble propósito atestar de la muerte efectiva del revolucionario y afirmar la propaganda anti-revolucionaria. Era entonces necesario fijar eternamente la imagen de ese cadáver para fijar en las mentes la supremacía de un mundo capitalista que no permite ninguna oposición. Ya que este es un problema de representación, lo podemos situar fácilmente en el terreno del cine preguntándonos qué podría articular el cine en oposición o en contrapeso a esta primera imagen impuesta a partir del cadáver del Che.

L 0 Está el plano de la foto del Che muerto que sale al final de La hora de los hornos (Fernando Solanas y Octavio Getino, 1968), ese plano eterno... los más fanáticos decían que el Che resucitaba en esa foto [risas]. Cada quien ve lo que quiere ver. En respuesta a ese plano Carlos Mayolo y yo hicimos el congelado final de ¡Oiga, Vea!, la mueca de la Monalisa del subdesarrollo que también fue portada del primer número de Ojo al Cine. De hecho, al grupo de Cali yo le puse unas fechas, y empieza en el 71, cuando hacemos esa película. Ese año empezó también el cine club de Cali, se hizo Angelita y Miguel Ángel, se fundó Ciudad Solar, en fin, hay muchos eventos que son fundacionales del grupo en ese mismo año. Ya después, en los noventa, a finales de los ochenta, es la época del 
narcotráfico en Cali, de un declive cultural fuerte y se da una diáspora de la gente del grupo que se va hacia Bogotá.

\section{Ver/filmar un cuerpo que se descompone}

Los registros de la liberación de los campos de concentración popularizaron las imágenes de las pilas de cadáveres amontonados, otorgándoles un carácter de testimonio que las amparaba de su morbidez y rapacidad. Su estatuto como prueba de lo acontecido, se supone, lograba apartarlas de lo obsceno. Aquello ha determinado tanto la manera en la que se representan los cadáveres en el cine, como la forma en la que asumimos dicha representación: rara vez encontramos imágenes de cadáveres domésticos o perdidos de una historia con $\mathrm{H}$ mayúscula; y ante las imágenes del horror, nuestra mirada se ampara por tratarse de una prueba testimonial, por poder reconocerlas como un vestigio de un acontecimiento histórico que nos otorga cierto "derecho a ver». Sin embargo, como bien afirma Susan Sontag, la exposición de imágenes del sufrimiento no necesariamente apela a la conciencia ni a la capacidad de compasión; por el contrario, puede corromperla. Aquellas imágenes -afirma- pasman, anestesian e incluso restan realidad. ¿Cuál es el límite cuando se filma un cuerpo muerto, su deshumanización, su descomposición? ¿Cuál es el límite cuando se filma un real cuya visibilidad es tan difícil de sostener?

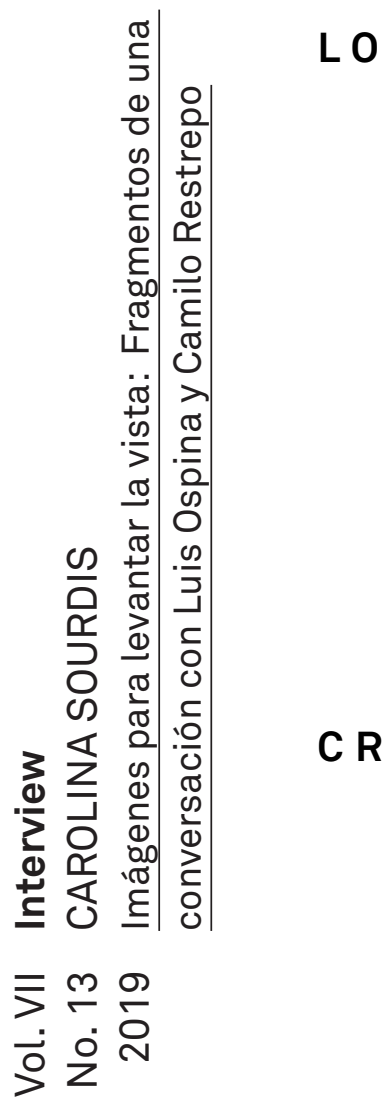

En Soplo de vida (1999), trabajo con imágenes de la tragedia de Armero. Para la película pude consultar muchísimos archivos tanto privados como de las programadoras de televisión y vi unas cosas terribles. Recuerdo las imágenes de Omayra Sánchez, son de las imágenes más icónicas que hay de alguien muriendo, en el tránsito de morir, y están muy ligadas al medio audiovisual porque todos los periodistas nacionales y del mundo se aprovecharon de esta situación y no pararon de tomar fotos y de filmar. Hay incluso grabaciones en donde la niña, ya con los ojos brotados, sanguinolentos, dice a los reporteros: «No more photographs, no photographs!». Es un caso en donde se junta la agonía atroz con los medios masivos audiovisuales.

En realidad, no soy capaz de imaginar un interés por la descomposición. Pero debo admitir que el poema de Baudelaire Une charogne es sin duda una obra en la que la imagen de 
la descomposición de un cuerpo es invocada con maestría y pertinencia. La imagen de la descomposición de un cadáver es un asunto muy delicado, en el sentido en que se acerca demasiado a la pornografía. El lector de Baudelaire sabe bien que Une charogne juega con esa proximidad. En el terreno del cine, frente a la pornografía prefiero la alusión.

Considero muy interesante construir la idea de la muerte en el cine en ese espacio que llamamos fuera de campo. Interesante porque de cierta manera es muy lógico hacerlo así. ¿Acaso la muerte no es ya ese fuera de campo de la vida, un fuera de campo que nos llama sin cesar la atención sobre la escena que vivimos?

Cuando yo hice Nuestra película (1993), en donde filmé al pintor Lorenzo Jaramillo muriendo de SIDA, descarté en el montaje imágenes de la última sesión de grabación cuando él ya estaba en la clínica en un estado de delirio. Decidí no usar esas imágenes, me sentí literalmente como un chulo, como un gallinazo... ¿Cómo dicen en España, como un buitre? Cuando filmábamos esas imágenes él no estaba en sus cabales, estaba alucinando. Por ejemplo, me decía: «¿Luis por qué no te tomas una copa de vino?». Yo le decía: «¿Lorenzo dónde está el vino?», y él me decía: «Ahí está encima de la mesa»; por supuesto no estaba. Yo no filmé literalmente su muerte, pero eso fue, creo, muy cercano. Para rodar esa película vi muchas películas sobre el SIDA y me molestaba un poco que a veces las personas que se filmaban no se veían muy bien, en cambio yo pienso que en toda mi película Lorenzo se ve muy guapo, no se ve en un estado terminal como en otras películas que se hicieron sobre el SIDA en ese momento. Y hay un pacto que uno hace con la persona que está muriendo: si ellos están de acuerdo o no en que uno los filme en ese estado. Antes de filmarlo realmente no era muy amigo de él, era más amigo de su hermana, lo había visto una vez en París y congeniamos muy bien, otra vez me lo encontré en la proyección de una película de Andy Warhol en el Museo de Arte Moderno de Bogotá, y ya después él me pidió la película de Andrés Caicedo para dársela a sus alumnos de la Universidad de los Andes. 0 sea, lo vi tres veces, y luego a través de su hermana acudí a su llamado: él estaba dispuesto a que yo lo filmara. Esa es, de hecho, la primera película que toca el tema del SIDA en Colombia. Al inicio de la película hago un pacto con Lorenzo y después le vuelvo a preguntar si le molesta que esté grabando, y él responde que no le importa si hay 100 cámaras, que lo único que le importa es decir lo que tiene que decir. 
En Todo comenzó por el fin filmé otro cuerpo

descomponiéndose, el mío, eso no estaba en el proyecto original porque yo me enfermé el primer día del rodaje de la película, la película iba a ser diferente, pero cuando yo vi que mi propio cuerpo era el que estaba flaqueando decidí perder un poco el pudor y hacerla abiertamente autobiográfica, mostrarme de la forma más descarnada posible. Yo había visto una película que me había impactado muchísimo: Sick: The Life and Death of Bob Flanagan, Supermasochist (1997), de Kyrby Dick, que, por cierto, cuando la vi casi todo el mundo abandonó la sala. Es un tipo que se hace filmar hasta la muerte, un artista sadomasoquista que se casa con una sádica; trabaja con su cuerpo y lo somete a todo tipo de torturas que disfruta. Se hace colgar con ganchos, la mujer le recoge todos los fluidos que le salen del cuerpo y los mete en unas botellas... es una relación muy particular. Para mí esa película logró romper la barrera que hay con el cuerpo y la enfermedad, porque él sufre de una enfermedad degenerativa y eso está documentado hasta que él prácticamente muere. Cuando decidí que yo mismo iba a filmar mi enfermedad y que otros iban a filmar mi cuerpo enfermo, pensé que había que romper la barrera del pudor. Salgo desnudo, en condiciones completamente vulnerables.

Al cadáver de Mayolo lo vi. Tan pronto murió, me llamó su compañera Beatriz Caballero y yo me fui para su casa. Nos fuimos varios amigos a ayudar, a ver qué se podía hacer, el papeleo de cuando se muere alguien, el aviso en la prensa; y entre todas esas cosas alcancé a verlo. Es el amigo más cercano que he visto muerto, incluso lo toqué, tuve ese impulso de tocarlo, le agarré la mano.

Cuando hice la película Todo comenzó por el fin encontré una imagen de él sentado, dormido en el mismo sillón en el que murió - porque Mayolo murió como un banquero suizo, leyendo el periódico El Siglo-. Beatriz estaba en el cuarto de al lado y no lo oyó, ella cuenta eso muy bien en la película. No es una imagen que yo haya filmado, la tomé de una película que hizo Roberto Triana sobre Mayolo (Mayolo de película, 2006) en donde él se queda dormido ahí. Dudé mucho si meterla justo en ese momento en el que Beatriz cuenta toda la secuencia de eventos del día en que Mayolo murió, porque estaba en ese borde de "Mierda, filmaron al tipo muriéndose», pero digamos que fue una licencia poética que yo decidí que estaba justificada y hay gente que cree que capturé el cadáver. 


\section{Imágenes para proyectar un rasgo de humanidad}

Orlando Fals Borda, uno de los pioneros de la sociología en Colombia quien abordó la época de La Violencia, apuntaba en 1960: «¿No será masoquista rumiar los temas tremendos de la violencia política-apenas una de las consecuencias sociales del odio-, repitiendo sus lúgubres detalles, rememorando suplicios y ultrajes, escarbando en el polvo sangriento de las masacres o en el lodo nauseabundo del detritus político, sin alcanzar a levantar la vista para descubrir alguna luz, alguna esperanza de respiro o salvación?» ${ }^{5}$. Casi sesenta años después, en medio de la saturación de imágenes y narrativas del conflicto armado más largo de América Latina, y en pleno auge de un respaldo civil a políticas estatales que proponen dar continuidad a la guerra, ¿podrá esa vasta y aterradora pila de imágenes de «nuestros» cuerpos muertos señalar algo de la singularidad del acontecimiento histórico? ¿Podría la imagen de un cadáver en Colombia remitir a otra cosa que no sea odio, maldad, violencia?

1/ El cuestionario incluía las siguientes preguntas: A veces para retratar mejor una montaña, para dimensionar su escala, necesitamos una figura humana: ¿Para rodar un cadáver es necesaria una figura viva?; Antígona cree que el cadáver insepulto de Polinices no solo contaminará el suelo, sino también el horizonte de Tebas. ¿Cómo rodar la descomposición de un cadáver, tendría interés?; Hitchcock, en Pero... ¿quién mató a Harry? (The Trouble with Harry, 1955), no deja que sus personajes tengan paz hasta que no se deshacen del cadáver. ¿Se puede hacer comedia con un cadáver? ¿Qué permitiría un cadáver que un cuerpo vivo no permitiría? ¿Cuál sería su función social?; Algunos cadáveres prototípicos del cine se asocian a los imaginarios de sus épocas: Frankenstein a los delirios frenéticos de la ciencia, los «zombis» a las contaminaciones de la era del SIDA. ¿Qué sintomatizan los cadáveres excesivos de Colombia?; La mejor, la peor y más macabra puesta en escena de un cadáver en Colombia ¿serían los «falsos positivos»?; ¿Qué rasgo de humanidad resiste más en un cadáver?; Reflexionando sobre el asesinato de Camilo Torres, en la película de Francisco Norden Camilo, el cura guerrillero (1974), García Márquez afirma que en América Latina solo creemos en los héroes muertos. Los líderes de los proyectos políticos populares en Colombia han sido asesinados: Gaitán, los líderes de la UP, Galán, los líderes sociales... ¿Qué dicen de nosotros esos cadáveres y qué podría articular el cine alrededor de éstos?; En noviembre de 1985 el Nevado del Ruiz hizo erupción. La tragedia nos dejó la transmisión de una muerte en directo. Omayra Sánchez, de 13 años, que, enterrada en los escombros, no pudo ser rescatada y murió frente a las cámaras. Ese mismo mes fue la toma al palacio por parte del M-19. ¿Cómo relacionas esas dos imágenes?

2/ La Violencia se refiere al periodo histórico en Colombia entre 1948-1958 en el que se dieron enfrentamientos entre seguidores de los partidos Conservador y Liberal. 
El detonante fue el asesinato de Jorge Eliécer Gaitán, líder popular y candidato a la presidencia del Partido Liberal, el 9 de abril de 1948. Este periodo se caracterizó por crímenes atroces entre ambos bandos y el desplazamiento forzado de millones de campesinos a las zonas urbanas.

3/ United Press International.

4/ Ver ARBELÁEZ y MAYOLO, 1975.

5/ Orlando Fals Borda (1960) en Soluciones sociales para los problemas del odio y la violencia. Actualidad Cristiana, año V, n. 20, p. 94. Citado en La Violencia en Colombia (GUZMÁN CAMPOS; FALS BORDA; UMAÑA LUNA, 2005: 225).

\section{Referencias bibliográficas}

ARBELÁEZ, Ramiro; MAYOLO, Carlos (1975). Camilo, el cura guerrillero. Ojo al Cine, No 2, pp. 80-83. Recuperado de: https://www.luisospina.com/archivo/ grupo-de-cali/revista-ojo-al-cine/ [acceso: 6 de mayo de 2019]

GUZMÁN CAMPOS, Germán; FALS BORDA, Orlando; UMAÑA LUNA, Eduardo (2005) [1962-1963]. La Violencia en Colombia. Estudio de un proceso social. Carlos Valencia Editores, 1980. 